\title{
Strategi Komunikasi Pemasaran CV. Abankirenk Yogyakarta dalam Meningkatkan Penjualan dimasa Pandemi Covid-19
}

\author{
Anggun Liliana Putri ${ }^{1}$, Dian Novita Kristiyani ${ }^{2}$, \\ Hubungan Masyarakat/Fakultas Teknologi Informasi/Universitas Kristen Satya Wacana \\ anggunlilianap@gmail.com ${ }^{1}$ /, Dian.kristiyani@uksw.edu, ${ }^{2}$
}

\begin{abstract}
During the Covid-19 pandemic, the creative industry for making school yearbooks was facing problems, because the government decided to close schools during the Covid-19 pandemic, eventually many student council programs did not go according to plan, one of which was making annual books because students had difficulty meeting, this is an impact on the decline in sales of school year book production. This study aims to determine the marketing communication strategy of CV.AbankIrenk Yogyakarta in increasing sales during the Covid-19 pandemic. This study used a qualitative approach by conducting in-depth interviews with the marekting team and direct observation at CV. AbankIrenk. From the results obtained, the marketing communication strategy carried out by CV. AbankIrenk Yogyakarta in increasing sales during the Covid-19 pandemic, namely adapting to the situation so that online marketing communications such as making presentations to introduce products and portfolios through zoom, google meet, conduct marketing communications through social media such as Instagram, Twitter, Tiktok, Youtube and a website to upload promotional content in the form of images, videos and text regarding the work owned by $C V$. AbankIrenk, and some information such as information about health protocols that have been implemented.
\end{abstract}

Keywords: Communication strategy, Marketing Communications, Social Media

\begin{abstract}
Abstrak
Di masa pandemi Covid-19 industri kreatif jasa pembuatan buku taunan sekolah sedang menghadapi masalah, dikarenakan pemerintah memutuskan untuk menutup sekolah selama pandemi Covid-19 akhirnya banyak program OSIS yang tidak berjalan sesuai rencana salah satunya pembuatan buku taunan karena siswa kesusahan untuk bertemu, hal ini berdampak pada menurunnya penjualan pembuatan buku taunan sekolah. Penelitian ini bertujuan untuk mengetahui strategi komunikasi pemasaran CV.AbankIrenk Yogyakarta dalam meningkatkan penjualan di masa pandemi Covid-19. Penelitian ini menggunakan pendekatan kualitatif dengan melakukan wawancara mendalam dengan tim marekting dan obseravasi secara langsung di CV. AbankIrenk. Dari hasil yang didapatkan, strategi komunikasi pemasaran yang dilakukan CV. AbankIrenk Yogyakarta dalam meningkatkan penjualan di masa pandemi Covid-19 yaitu berusaha untuk beradaptasi dengan keadaan sehingga strategi pemasaran dan komunikasi pemasaran yang dilakukan oleh CV. AbankIrenk dilakukan secara online melalui media sosial yang dimiliki oleh CV. AbankIrenk.
\end{abstract}

Kata Kunci: Strategi Komunikasi, Komunikasi Pemasaran, Media Sosial 


\section{PENDAHULUAN}

Di masa pandemi Covid-19 sekarang ini industri kreatif jasa pembuatan buku tahunan yang berisi tentang catatan kegiatan dalam tahun terakhir sedang menghadapi masalah, karena di masa pandemi Covid-19 pemerintah memutuskan untuk menutup sekolahan. Karena kebijakan yang dibuat oleh pemerintah untuk masyarakat seperti menjaga jarak, karantina wilayah berpengaruh terhadap perekonomian yang sangat signifikan terhadap industri, pariwisata, perhotelan dan masih banyak lainnya (Sari, 2020:1)

Pandemi Covid-19 ini sangat berbahaya karena bisa membuat orang yang terkena virus tersebut meninggal dunia, penyebarannya pun sangat cepat. Penyebarannya bisa melalui udara, menyentuh benda dan kontak langsung dengan orang yang terkena virus Covid-19. Untuk mencegah penyebaran Covid-19 yang semakin luas pemerintah membuat kebijakan baru untuk masyarakat untuk tetap dirumah, bekerja dari rumah, belajar dirumah, melakukan ibadah dari rumah dan dilarang mengadakan kerumunan massa (Larasati, 2020:500)

Hal ini yang membuat pemerintah membuat kebijkan untuk menutup sekolahan sementara karena proses pembelajaran dilakukan dari rumah dan dilarang mengadaka kerumunan massa. Penutupan sekolahan ini mengakibatkan program OSIS yang tidak berjalan sesuai rencana karena siswa kesusahan untuk bertemu karena kebijakan dari pemerintah juga melarang adanya perkumpulan masa, hal tersebut juga membuat penurunan penjualan pembuatan buku taunan.

Pembuatan buku tahunan merupakan program OSIS setiap tahunnya yang dibuat untuk anak-anak kelas 12 yang sudah mau lulus, sehingga OSIS membuat buku tahunan yang bisa dijadikan kenangan bagi kelas 12 nantinya. Sehingga jika pembuatan buku tahunan tidak terlaksana program OSIS tidak berjalan dengan sesuai dan anak-anak kelas 12 tidak memiliki buku tahunan yang dijadikan kenangan nantinya.

Namun di masa pandemi Covid-19 ini, masih banyak industri kreatif pembuatan buku tahunan di Indonesia yang tetap beroperasi dan tetap menawarkan jasa nya kepada sekolahansekolahan dengan harapan industri kreatifnya yang dimilikinya tetap bisa berjalan dengan baik dan penjualannya tetap meningkat. Karena banyaknya sekolahan yang tutup dan berkurangnya sekolahan yang membuat buku taunan sekolah pastinya persaingan untuk mendapatkan klien di masa pandemi Covid-19 semakin meningkat.

Untuk mengatasi persaingan tersebut dibutuhkan strategi komunikasi pemasaran yang tepat untuk industri kreatif tersebut memperkenalkan produknya melalui strategi komunikasi pemasaran yang dibuat dan di rencanakan dengan tujuan untuk mendapatkan klien dan membuat klien percaya untuk menjalin kerjasama dengan industri kreatif tersebut.

Sehingga dibutuhkannya strategi komunikasi pemasaran, karena komunikasi dan pemasaran saling berkaitan satu sama lain karena dalam melakukan pemasaran membutuhkan komunikasi karena dengan adanya komunikasi yang baik pemasaran bisa berjalan dengan efektif dan efisien. Hal ini bertujuan untuk menyadarkan masyarakat akan keberadaan industri kreatif tersebut, kenal dan akhirnya tertarik dengan produk yang dihasilkan oleh industri kreatif tersebut melalui komunikasi yang baik (Prisgunanto, 2006:7)

Salah satu industri kreatif yang terkena dampak dari pandemi Covid-19 adalah CV. AbankIrenk, CV. AbankIrenk merupakan industri kreatif pencetus pembuatan buku tahunan sekolahan di Indonesia yang berada di Jalan Tampungan 90 Brebah, Sleman Yogyakarta. CV. AbankIrenk berdiri pada tahun 2004 hingga sekarang, sehingga sudah banyak sekolahan yang mengenal dan menggunakan jasa $\mathrm{CV}$. AbankIrenk untuk pembuatan buku tahunan sekolahan. $\mathrm{CV}$. AbankIrenk tidak hanya melayani pembuatan buku tahunan di daerah Jawa saja, tetapi 
banyak sekolahan di luar Jawa seperti Bali, Palembang, dll yang menggunakan CV. AbankIrenk dalam pembuatan buku taunan sekolahan.

\section{Tabel 1. Jumlah Sekolahan yang Menggunakan CV. AbankIrenk Dalam Pembuatan} Buku Tahunan dari Tahun 2016 - 2020

\begin{tabular}{|l|l|l|l|l|l|}
\hline Wilayah & $\mathbf{2 0 1 6}$ & $\mathbf{2 0 1 7}$ & $\mathbf{2 0 1 8}$ & $\mathbf{2 0 1 9}$ & $\mathbf{2 0 2 0}$ \\
\hline Yogyakarta & $\mathbf{4 0}$ & $\mathbf{3 3}$ & $\mathbf{4 0}$ & $\mathbf{3 1}$ & $\mathbf{3 5}$ \\
\hline Jakarta & $\mathbf{2 5}$ & $\mathbf{2 4}$ & $\mathbf{3 0}$ & 35 & $\mathbf{3 2}$ \\
\hline $\begin{array}{l}\text { Jawa } \\
\text { Tengah }\end{array}$ & $\mathbf{4 0}$ & $\mathbf{3 5}$ & $\mathbf{4 0}$ & $\mathbf{4 7}$ & $\mathbf{3 9}$ \\
\hline Jawa Barat & $\mathbf{2 5}$ & $\mathbf{3 5}$ & $\mathbf{3 1}$ & $\mathbf{3 5}$ & $\mathbf{3 2}$ \\
\hline Jawa Timur & $\mathbf{3 1}$ & $\mathbf{4 3}$ & $\mathbf{3 5}$ & $\mathbf{3 5}$ & $\mathbf{3 7}$ \\
\hline Luar Jawa & $\mathbf{3 1}$ & $\mathbf{3 0}$ & $\mathbf{3 1}$ & $\mathbf{3 2}$ & $\mathbf{3 0}$ \\
\hline Jumlah & $\mathbf{1 9 2}$ & $\mathbf{2 0 0}$ & $\mathbf{2 0 7}$ & $\mathbf{2 1 5}$ & $\mathbf{2 0 5}$ \\
\hline
\end{tabular}

Sumber: Bag.Marketing CV.AbankIrenk Yogyakarta

Sesuai dengan data yang didapat dari bagian marketing CV. AbankIrenk Yogyakarta, dari tahun 2016 - 2019 jumlah sekolahan yang menggunakan jasa CV. AbankIrenk dalam pembuatan buku tahunan sekolah mengalami kenaikan seperti di tahun 2016 berjumlah 192, di tahun 2017 berjumlah 200, di tahun 2018 berjumlah 2017 dan di tahun 2019 berjumlah 205, sehingga penjualan jasa pembuatan buku tahunan di CV. AbankIrenk terus meningkat.

Tetapi, pada tahun 2020 penjualan di CV. AbankIrenk mengalami penurunan karena jumlah sekolahan yang menggunakan jasa CV. AbankIrenk dalam pembuatan buku tahunan sekolah hanya berjumlah 205 sehingga penjualan mengalami penurunan yang signifikan. Hal ini disebabkan karena pada tahun 2020 Indonesia sedang mengalami pandemi Covid-19 yang menyebabkan penutupan sekolah sesuai dengan kebijakan yang dibuat oleh pemerintah untuk mencegah penyebaran Covid-19 yang semakin meluas.

Untuk mengatasi masalah tersebut dan tetap meningkatkan penjualan di masa pandemi Covid-19 CV. AbankIrenk membutuhkan strategi komunikasi pemasaran yang tepat yang bisa digunakan untuk meningkatkan penjualannya di masa pandemic Covid-19.

Strategi komunikasi pemasaran merupakan suatu cara yang sederhana atau moderen yang mengikuti perkembangan zaman yang dilakukan oleh perusahaan atau industri untuk memperkenalkan produknya kepada masyarakat luas dan harapannya bisa mendapatkan konsumen sebanyak-banyaknya, sehingga nantinya penjualan semakin meningkat

Dalam mengatasi penurunan penjualan pembuatan buku taunan sekolahan $\mathrm{CV}$. AbankIrenk memiliki strategi komunikasi pemasaran yang tepat untuk mengatasi permasalahan tersebut dan membuat penjualannyan tetap meningkat dengan cara membuat strategi pemasaran yang tepat dan menggunakan komunikasi pemasaran yang sesuai dengan cara menggunakan media sosial yang sesuai dengan target. 


\section{TINJAUAN PUSTAKA}

\section{Strategi Pemasaran}

Menurut Sofjan Assauri strategi pemasaran merupakan suatu perencanaan yang menyeluruh, terpadu dan menyatu, yang memberikan cara-cara mengenai kegiatan yang akan dilakukan untuk mencapai tujuan pemasaran bagi suatu perusahaan (Assauri, 2002:154).

Dalam buku Manajemen Strategi Pemasaran Kotler dan Amstrong menyatakan bahwa strategi pemasaran merupakan logika pemasaran, yang dimana suatu perusahaan atau unit bisnis apapun berharap bisa mencapai tujuan pemasaran (Abdurrahman, 2015:16).

Menurut Fandy Tjiptono strategi pemasaran merupakan suatu rencana yang dibuat dan diikuti oleh manajer pemasaran sebagai bahan acuan. Rencana tindakan ini dibuat berdasarkan situasi yang ada dan tujuan yang dimiliki perusahaan dan cara untuk mencapai tujuan (Tjiptono, 2000:43).

\section{Komunikasi Pemasaran}

Komunikasi pemasaran merupakan cara yang digunakan oleh perusahaan untuk menginformasikan, membujuk dan mengingatkan kepada konsumen mengenai produk atau merek yang dijualnya, baik secara langsung maupun tidak (Kotler Phillip, 2012:498)

Komunikasi pemasaran merupakan komunikasi dengan tujuan melakukan kegiatan pemasaran terhadap suatu perusahaan perusahaan. Komunikasi pemasaran dipengaruhi oleh beberapa hal seperti media yang digunakan, daya tarik pesan dan frekuensi layanan. Aplikasi komunikasi dalam bisnis memiliki peran yang sangat penting karena dalam penyampaian pesan, komunikasi yang menghadapi berbagai masalah seperti perbedaan budaya, perbedaan cara pandang, dan keterbatasan media yang digunakan (Dimyati, 2015:75)

Komunikasi pemasaran merupakan kegiatan pemasaran yang bertujuan untuk menciptakan kesadaran akan produk yang dijualnya dan memberikan pengetahuan mengenai produk yang dijualnya dengan menggunakan berbagai cara seperti memberikan informasi mengenai kelebihan produk, menciptakan citra terhadap produk tersebut, menciptakan sikap positif dan menimbulkan keinginan untuk membeli produk tersebut, yang termasuk dalam komunikasi pemasaran terpadu antara lain periklanan, promosi penjualan, publisitas, penjualan perseorangan, hubungan masyarakat dan penjualan langsung, kemasan, sponsorship dan customer service (Morissan, 2007:133).

\section{Media Sosial}

Menurut Rulli Nasrullah dalam bukunya yang berjudul Media Sosial menyatakan bahwa "Media Sosial merupakan medium dalam internet yang bisa membuat penggunannya untuk mempresentasikan dirinya maupun berinteraksi, bekerjasama, saling berbagi, berkomunikasi dengan pengguna lainnya, dan membentuk ikatan sosial secara virtual " (Nasrullah, 2016:13).

Media Sosial menurut Philip Kotler dan Kevin Keller yaitu media sosial merupakan tempat bagi konsumen untuk berbagi informasi dalam bentuk teks, gambar, video, dan audio dengan satu sama lain, dengan perusahaan dan sebaliknya (Kotler Phillip, 2012:568).

Menurut Zarella media sosial atau jejaring sosial merupakan situs yang menjadi tempat untuk orang-orang bekomunikasi dengan teman-teman mereka, yang mereka kenal di dunia maya maupun dunia nyata (Zarella, 2010:51). 


\section{METODE PENELITIAN}

Dalam melakukan penelitian mengenai strategi komunikasi pemasaran yang dilakukan oleh CV. AbankIrenk dalam meningkatkan penjualan dimasa pandemi Covid-19, penelitian ini menggunakan metode penelitian pendekatan kualitatif. Penelitian kualitatif sendiri merupakan penelitian yang menghasilkan sebuah data deskriptif dalam bentuk katakata, gambar tetapi bukan dalam bentuk angka, yang didapat dari orang-orang atau perilaku yang bisa diamati

Metode pengumpulan data yang dilakukan oleh peneliti dengan cara melakukan observasi secara langsung dilapangan, melakukan wawancara dengan beberapa narasumber yaitu head marketing CV . AbankIrenk ( Mas Fajri )dan beberapa staff marketing CV. AbankIrenk ( Mas Pandu, Mbak Dwi dan Mas Budiman ) dan dokumen yang berisi dengan data yang diperlukan oleh peneliti. Untuk melakukan validitas data menggunakan triangulasi data.

\section{HASIL DAN PEMBAHASAN}

Strategi pemasaran merupakan salah satu faktor yang paling penting di suatu perusahaan yang memiliki peran penting dalam meningkatkan penjualan suatu produk karena strategi pemasaran merupakan sebuah proses untuk meningkatkan penjualan, sehingga strategi pemasaran merupakan alat yang penting bagi perusahaan untuk mampu memenangkan persaingan (Prawirosentono, 2004:152)

Sehingga di masa pandemic Covid-19 untuk meningkatkan penjualannya CV. AbankIrenk membuat strategi pemasaran yang tepat yang bisa menarik perhatian para klien, strategi pemasaran yang dibuat oleh CV. AbankIrenk dibuat dengan cara melihat keadaan di lapangan dan melihat situasi di masa pandemi Covid-19. Strategi-strategi pemasaran yang sudah di rencanakan tersebut nantinya akan dijadikan panduan oleh CV. Abankirenk dalam usaha untuk meningkatkan penjualannya di masa pandemi Covid-19.

Seperti pada masa pandemi Covid-19 sekarang ini CV. AbankIrenk memberikan diskon $25 \%$ yang bertujuan untuk menarik minat klien untuk menggunakan jasa pembuatan buku taunan sekolahan, pemberian diskon $25 \%$ sesuai dengan keadaan di masa pandemi Covid-19 dimana keadaan ekonomi sedang tidak baik sehingga berpengaruh ke berbagai aspek, dengan adanya diskon $25 \%$ bisa mempengaruhi klien untuk menjalin kerjasama dengan CV. AbankIrenk. Karena dengan adanya diskon 25\% harga yang ditawarkan akan lebih murah dari harga biasanya.

Dengan adanya diskon $25 \%$ pastinya menguntungkan kedua belah pihak karena klien akan mendapatkan harga yang lebih murah dari pada biasanya dan CV. AbankIrenk akan mendapatkan keuntungan karena jika semakin banyak pesanan pembuatan buku taunan yang masuk akan mengurangi biaya produksi selain itu dengan adanya diskon $25 \%$ bisa memenangkan pasar karena biaya yang lebih murah.

$\mathrm{CV}$. AbankIrenk juga membuat strategi pemasaran yang melihat situasi di lapangan yang ada, seperti kendala yang dialami dalam melakukan proses produksi pengambilan foto para konsumen kebingungan karena sesuai dengan kebijakan dari pemerintah untuk belajar dari rumah dan larangan untuk berkumpul masa akhirnya sekolahan ditutup, sehingga tidak ada tempat untuk melakukan proses produksi pengambilan foto.

Sehingga untuk mengatasi permasalahan tersebut CV. AbankIrenk membuat strategi pemasaran dengan cara mengadakan free studio on delivery, diadakannya free studio on delivery tidak hanya untuk mengatasi masalah tersebut tetapi juga untuk membuat klien 
tertarik untuk menggunakan CV. AbankIrenk dalam pembuatan buku tahunan. Karena dengan adanya free studio on delivery mempermudah klien pada saat proses produksi untuk pengambilan foto.

Dan cara untuk memesan free studio on delivery pun mudah hanya dengan cara memesan secara online menghubungi melalui media sosial, telefon atau sms saja. Sehingga penawaran ini sangat mempengaruhi para klien CV. AbankIrenk untuk menjalin kerjasama dan dengan adanya free studio on delivery juga mengatasi permasalahan pada bagian tim fotografer karena melihat jadwal produksi pada bulan Juli para fotografer tidak terlalu banyak memiliki pekerjaan sehingga untuk memanfaatkan waktu dan meningkatkan penjualan di masa pandemi Covid-19 CV. AbankIrenk mengadakan free studio on delivery.

CV. AbankIrenk juga mengadakan acra AbankBagiTHR yang dilaksanakan berdekatan dengan hari raya lebaran dengan total hadiah jutaan rupiah yang nantinya hadiah tersebut bisa digunakan oleh para klien untuk acara buka bersama atau acara lainnya

Dalam acara ini terdapat ketentuan yang harus dilakukan seperti mengajak minimal 4 teman dengan tag nama teman kalian di kolom komentar tujuannya diadakan ketentuan tersebut adalah agara semakin banyak orang yang tau media sosial instagram $\mathrm{CV}$. AbankIrenk dan setelah mengunjungi dan melihat hasil karya yang dimiliki CV. AbankIrenk melalui postingan feed instagram CV. AbankIrenk banyak anak-anak sekolahan yang tertarik untuk menjalin kerjasama dengan $\mathrm{CV}$. AbankIrenk sehingga nantinya penjualan akan meningkat.

Para klien tertarik dengan adanya acara AbankBagiTHR karena acaranya tidak dipungut biaya, hal ini juga dibuktikan dengan video atau foto sekolahan yang mengikuti acara tersebut yang terdapat feed instagram CV. AbankIrenk dan keuntungan yang di dapat oleh CV. AbankIrenk yaitu like, new followers, dll.

Di masa pandemi Covid-19, CV. AbankIrenk tetap berusaha untuk mengembangkan inovasi dengan cara mengadakan direct marketing melalui telemarketing. Hal ini bertujuan untuk memasarka jasa pembuatan buku tahunan yang di miliki oleh CV. AbankIrenk dengan biaya pemasaran yang lebih rendah dan mempermudah para klien yang ingin bertanya mengenai seputar pembuatan buku tahunan dan brainstorm bisa dilakukan secara online sehingga klien tidak perlu mengunjungi kantor CV. AbankIrenk selama pandemi Covid-19.

Dengan adanya direct marketing proses pemasaran semakin efektif dan efisien karena klien bisa berhubungan secara langsung dengan CV. AbankIrenk melalui media sosial atau telepon, mempermudah telemarketing untuk menjangkau klien dan bisa mengetahui respon klien secara langsung tanpa harus membuat perjanjian untuk bertemu.Selain itu, klien juga bisa melakukan booking online melalui direct marketing sehingga dalam melakukan pemasaran akan lebih efektif dan efisien.

CV. AbankIrenk dimasa pandemi Covid-19 juga berusaha untuk memperluas jaringan agar semakin dikenal oleh banyak orang sehingga nantinya dalam pemasaran akan lebih mudah, untuk memperluas jaringan CV. AbankIrenk melakukan kolaborasi dengan Does University yang merupakan sekolah animasi dan mengadakan kolaborasi dengan Isa Indra Permana yang merupakan salah satu seniman, ilustrator, dan disainer.

Dengan jaringan yang luas mempermudah untuk orang-orang mengetahui eksistensi keberadaan CV. AbankIrenk sehingga hal tersebut bisa mempengaruhi klien untuk menggunakan CV. AbankIrenk karena eksistensi keberadaanya sudah dikenal luas.

Dalam melakukan strategi pemasaran yang dimiliki oleh suatu perusahaan atau industri kreatif pastinya tidak bisa terlepas dari yang namanya komunikasi pemasaran. karena 
strategi pemasaran dan komunikasi pemasaran saling melengkapi dan saling membutuhkan. Karena komunikasi pemasaran merupakan suatu sarana yang digunakan oleh suatu perusahaan atau industri kreatif untuk menginformasikan, membujuk dan mengingatkan klien baik secara langsung maupun tidak langsung mengenai produk dan merk yang dihasilkan (Kotler Phillip, 2012:498)

Komunikasi pemasaran yang dilakukan oleh CV. AbankIrenk di masa pandemi Covid-19 yaitu dengan cara online melalui media sosial seperti instagram, twitter, dan tiktok yang sesuai dengan media sosial yang sedang digemari oleh target sasaran. Media sosial menjadi etalase paling depan dalam melakukan komunikasi pemasaran karena dalam melakukn komunikasi pemasaran tidak perlu mengeluarkan biaya dan informasi yang di unggah di media sosial bisa tersebar luas sehingga dalam melakukan komunikasi pemasaran akan lebih efektif dan efisien.

Selain itu, melalui media sosial CV. AbankIrenk juga berusaha untuk membujuk masyarakat untuk menggunakan jasanya dengan cara menunjukan hasil karya yang ditampilkan di halaman media sosial CV. AbankIrenk yang bertujuan untuk membangun kepercayaan klien terhadap CV. AbankIrenk.

Tidak hanya untuk membujuk tetapi CV. AbankIrenk juga berusaha untuk berinteraksi dan berusaha untuk selalu terhubung dengan klien agar komunikasi antara CV. AbankIrenk dengan para klien tetap baik harapannya agar klien akan menjalin kerjasama ulang dengan CV. AbankIrenk.

CV . AbankIrenk juga berusaha untuk beradaptasi dengan keadaan pandemi Covid-19, sehingga komunikasi pemasaran yang biasanya secara langsung dengan cara datang ke sekolahan selama pandemi Covid-19 CV. AbankIrenk berusaha untuk melakukan komunikasi melalui zoom, googlemeet,dll

$\mathrm{CV}$. AbankIrenk menggunakan zoom, googlemeet, dll untuk memasarkan produk dan jasa yang mereka tawarkan lalu menampilkan portofolio yang dimiliki oleh CV. AbankIrenk seperti hasil karya yang bisa mempengaruhi minat klien. CV. AbankIrenk juga mengirim sempel buku taunan dari sekolahan lain kepada klien untuk mendapatkan kepercayaan.

Komunikasi pemasaran yang dilakukan oleh CV. AbankIrenk selanjutnya yaitu menjadi sponsorship di acara pentas seni yang dilaksanakan oleh klien. Tujuan CV. Abankirenk menjadi sponsor untuk menjalin kerjasama dengan klien, selain itu menjadi sponsors di suatu acara bisa menjadi media iklan bagi CV. AbankIrenk untuk memperkenalkan produk dan jasa yang dimiliki dengan cara melalui publikasi atau media massa yang meliput acara pentas seni tersebut. Dengan menjadi sponsorship di suatu acara yang diselenggarakan oleh klien bisa digunakan untuk mengkomunikasikan pemasaran karena nantinya nama $\mathrm{CV}$. AbankIrenk akan disebut dalam acara tersebut yang dihadiri oleh tamu yang berasal dari berbagai sekolah sehingga semakin banyak orang yang akan mengenal dan menjadi sponsorship juga merupakan tanggung jawab kepada sosial dan membangun hubungan baik dengan klien.

Di masa pandemi Covid-19 CV. AbankIrenk dalam melakukan komunikasi pemasaran untuk menyebarkan informasi menggunakan media sosial dan website sehingga klien akan lebih mudah untuk mendapatkan informasi yang mereka butuhkan. Sehingga CV. AbankIrenk selalu memperbarui informasi terbaru secara terus menerus melalui media sosial dan website. Website digunakan untuk membuat klien percaya dan terlihat profesional, selain itu di website memberikan informasi yang lebih jelas. 
Melalui media sosial dan website para klien bisa bertanya-tanya mengenai CV. AbankIrenk, CV. AbankIrenk juga mengadakan whatsapp di websitenya untuk mempermudah klien untuk langsung terhubung dengan whatsapp yang dimiliki oleh $\mathrm{CV}$. AbankIrenk dengan cara mengeklik icon whatsapp.

Media sosial dan website sangat membantu CV. AbankIrenk di masa pandemi Covid19 untuk meningkatkan penjualannya karena mempermudah untuk bertukar informasi secara cepat dengan cakupan wilayah yang luas. Dan apabila CV. AbankIrenk sering melakukan iklan dan promosi maka bisa berpeluang besar untuk orang-orang mengunjungi media sosial CV. AbankIrenk.

Dalam melakukan komunikasi pemasarannya melalui media sosial CV. AbankIrenk membuat konten dalam bentuk audio, video, gambar dan teks yang bisa menarik perhatian klien. Hal ini sesuai dengan pendapat menurut Philip Kotler dan Kevin Keller yang menyatakan bahwa media sosial adalah tempat bagi konsumen untuk memberikan informasi dalam bentuk audio, video, teks dan gambar dengan satu sama lain dan dengan perusahaan sebaliknya (Kotler Phillip, 2012:568).

Seperti konten protokol kesehatan yang diunggah di instagram dan tiktok dalam bentuk foto dan video. Tujuan dibuatnya konten tersebut dalam bentuk foto dan video yaitu menunjukan kepada klien jika CV. AbankIrenk sudah menerapkan protokol kesehatan di masa pandemi Covid-19, sehingga klien tidak ragu untuk bekerjasama dengan $\mathrm{CV}$. AbankIrenk untuk membuat buku taunan.

Melalui media sosial instagram CV. AbankIrenk, CV. AbankIrenk sering membuka sesi tanya jawab yang menggunakan fitur tanya jawab yang ada di media sosial instagram yang bertujuan untuk berinteraksi dengan klien untuk menjaga hubungan baik juga berharap klien tersebut akan menjalin kerjasama lagi dan untuk menjawab pertanyaan dari orang-orang yang ingin mengetahui informasi mengenai CV. AbankIrenk.

Melalui channel youtube yang dimiliki oleh CV. AbankIrenk membuat serial baru yang bertujuan untuk menemani para klien yang merasa bosan selama stay at home di masa pandemi Covid-19, tidak hanya membuat serial baru di channel youtube CV. AbankIrenk juga membuat daftar lagu yang bisa didengarkan pada waktu bosan saat stay at home di masa pandemi Covid-19.

Dengan dibuatnya album lagu di spotify dan serial baru di youtube tersebut oleh CV. AbankIrenk diharapkan bisa menunjukan kepada orang-orang di masa pandemi $\mathrm{CV}$. AbankIrenk masih bisa berkreasi dan tetap bisa mendekatkan hubungan dengan klien.

\section{SIMPULAN}

Dari hasil penelitian mengenai strategi komunikasi pemasaran yang dilakukan oleh CV.AbankIrenk dalam meningkatkan penjualan di masa pandemi Covid-19, maka dapat disimpulkan bahwa:

(a) strategi pemasaran yang dibuat melihat keadaan lapangan atau situasi yang ada dan dibuat semenarik mungkin untuk menarik perhatian para klien. Dengan memberikan potongan harga kepada klien bisa menarik perhatian klien karna harga yang di dapat lebih murah dari pada harga biasanya. Selain memberikan potongan harga, CV. AbankIrenk juga mengadakan free studio on delivery juga sangat mempengaruhi minat klien untuk menjalin kerjasama karena bisa mengtasi kendala yang dialami klien karna tidak ada tempat untuk 
melakukan proses produksi pengambilan foto. Mengadakan acara AbankBagiTHR digunakan untuk menyadarkan masyarakat akan eksistensi keberadaan. Dengan adanya direct marketing sangat mempermudah interaksi antara klien dengan CV. AbankIrenk dan bisa mengetahui respon klien secara langsung tanpa harus bertemu. Dengan mengadakan kolaborasi bisa memperluas jaringan agar semakin dikenal sehingga nantinya dalam melakukan pemasaran akan lebih mudah.

(b) Komunikasi pemasaran yang dibuat oleh CV. AbankIrenk berusha menyesuaikan keadaan di masa pandemi Covid-19 yang dimana semuanya serba online, sehingga untuk melakukan komunikasi pemasarannya bisa memanfaatkan media sosial, zoom, gmeet, website, dll. Untuk melakukan komunikasi pemasaran CV. AbankIrenk menjadi sponsorship di acara yang di selenggarakan oleh klien karna bisa menjadi media iklan.

(c) Media sosial sebagai platfrom untuk melakukan pemasaran akan produk yang dijualnya karena media sosial sangat efektif dan efisien untuk melakukan penyebaran informasi secara luas seperti misalnya membuat konten tentang protokol kesehatan sehingga klien tidak ragu untuk bekerjasama karena sudah sesuai dengan protokol kesehatan. Melalui media sosial kita juga bisa berinteraksi dengan klien secara langsung atau menjawab pertanyaan-pertanyaan klien secara langsung tanpa harus bertemu. Pembuatan serial film dan album di spotify untuk klien merupakan cara untuk melakukan pendekatan kepada klien agar hubungan terjalin dengan baik.

\section{Saran}

Saran dalam penelitian ini, antara lain:

Dalam mengadakan acara giveaway seperti AbankBagiTHR bisa menambahakan ketentuan untuk wajib memfollow akun instagram CV. AbankIrenk dan merepost ulang konten AbankBagiTHR sehingga dengan cara seperti ini banyak orang akan tau akun instagram CV. AbankIrenk.

Untuk komunikasi pemasaran melalui media sosial twitter sebaiknya lebih sering mengupdate berita terbaru mengenai $\mathrm{CV}$. AbankIrenk karena banyak target sasaran yang masih banyak menggunakan media sosial twitter dan untuk komunikasi pemasaran melalui media sosial tiktok sebaiknya lebih sering diupdet karena media sosial tiktok merupakan media sosial yang sedang digemari banyak orang

Dalam pembuatan serial terbaru di youtube jangan terlalu lama jangka waktu dalam mengupdate konten dan membuat konsep dengan sebaik mungkin agar lebih menarik dan untuk album lagu di spotify diusahakan untuk terus berjalan.

\section{DAFTAR PUSTAKA}

Abdurrahman, N. H. (2015). Manajemen Strategi Pemasaran. CV. Pustaka Setia. Assauri, S. (2002). Manajemen Pemasaran Dasar, Konsep, dan Strategi. PT. Raja Grafindo Persada.

Dan Zarella. (2010). The Social Media Marketing Book. Oreilly Media.

Dimyati, M. (2015). the Role of Customer Satisfaction in Mediating Marketing Communication Effect on Customer Loyalty. Researchers World-Journal of Arts Science \& Commerce, VI(4(1)), 75-87. https://doi.org/10.18843/rwjasc/v6i4(1)/09 
Kotler Phillip, K. L. (2012). Marketing Management. PT. Indeks Kelompok Gramedia.

Larasati, D. (2020). Pembelajaran Di Masa Pandemi Covid-19 Work From Home. Wineka Media.

Morissan. (2007). Periklanan dan Komunikasi Pemasaran Terpadu. Ramdina Prakarsa.

Nasrullah, R. (2016). Media Sosial: Perspektif Komunikasi, Budaya, Sosioteknologi.

Simbiosa Rekatama Media.

Prawirosentono, S. (2004). Filosofi Baru Tentang Manajemen Mutu Terpadu Total Quality Management abad 21 Studi kasus \& Analisis. PT Bumi Aksara.

Prisgunanto, I. (2006). Komunikasi Pemasaran Strategi \& Taktik. Ghalia Indonesia.

Sari, Y. I. (2020). Sisi Terang Pandemi Covid-19. Jurnal Ilmiah Hubungan Internasional, O(0), 89-94. https://doi.org/10.26593/jihi.v0i0.3878.89-94

Tjiptono, F. (2000). Manajemen Jasa. Andy Offset. 